\title{
DIFFERENTIAL RESPONSE OF FABA BEAN (VICIA FABA L.) PLANTS TO WATER DEFICIT AND WATERLOGGING STRESSES
}

\author{
AL-AMRI, S. M. \\ Biology Department, Shaqra Faculty of Science and Arts, Shaqra University \\ Shaqra, Saudi Arabia \\ (e-mail: asenany203@yahoo.com) \\ (Received 23 ${ }^{\text {rd }}$ Dec 2018 ; accepted 11 $1^{\text {th }}$ Apr 2019)
}

\begin{abstract}
Most of literature on water deficit and water logging tolerance and resistance in faba bean, have not be widely studied. Therefore, it is important to study the different plant responses to these abiotic stresses to understand the mechanisms of tolerance. Towards this goal faba bean plants were cultivated in soil culture at different levels of field capacity, $\mathrm{FC}$ (Control), $2 \mathrm{FC}$ (flooding), $75 \%$ of $\mathrm{FC}$, low water deficit (LWD) and 50\% of FC, high water deficit (HWD), for 2 weeks. Fresh and dry weights of plant roots and shoots were significantly decreased under both water stresses (flooding and water deficit). Number of plant nodules was affected as exposed to high and low water deficit levels (75\% \& 50\% FC) by about $47 \%$ and $5 \%$, respectively. Alcohol dehydrogenase specific activity of bean roots grown under flooding stress was significantly increased as compared to absolute control while the specific activity of alcohol dehydrogenase activity (ADH) under the two levels of drought ( $75 \%$ \& 50\% FC) was less affected as compared to reference control. Also, Michael's constant $\left(\mathrm{K}_{\mathrm{m}}\right)$ and maximum velocity $\left(\mathrm{V}_{\max }\right)$ of $\mathrm{ADH}$ in bean roots was decreased under the two levels of drought $(75 \%$ \& $50 \% \mathrm{FC})$ and flooding stress (2FC) compared to absolute control. Transfers cross sections stained with safranin examined and photographed at $25 \mathrm{X}$ of 3-weeks old roots of flooded faba been plants showing loosely parenchymal cell of cortex containing many and large intercellular spaces as compared to control and droughted plants. We concluded that flooding cause damage to Vicia faba plant more than water deficit through its effects on nodule formation and activity.
\end{abstract}

Keywords: water stress, legumes, alcohol dehydrogenase activity (ADH)

\section{Introduction}

Abiotic stress is a major constraint for agricultural production allover the world and drought is the most important limiting factor (Asgher et al., 2017; Hussain et al., 2018). Water deficit and flooding stresses have a negative impact on the living organisms in a specific environment (Armstrong, 1971a, b; El-Enany et al., 2014). The combination of environmental stresses always leads to cellular damage and causes a series of morphological, physiological, biochemical and molecular changes in plant growth, development and productivity (Gao et al., 2007; Mittler et al., 2006). Boyer (1982) and Araus et al. (2002) stated that exposure to water deficit or waterlogging stresses cause metabolism disturbance and damage to biomolecules. Frequent occurrence of climatic extremes water deficit and/or flooding every year in several parts of the world has adversely affected production of may crops (Candian and Tarhan, 2012). As a result, water deficit and waterlogging of the soil have become apparent in crop yields (Parent et al., 2008; Ashraf and Irm, 2005). Plants respond to environmental stresses at morphological, anatomical, cellular and molecular levels, leaf development (Cutler et al., 1980), maintain root development and soil moisture extraction and delayed leaf senescence (Hsiao et al., 1985).

Waterlogging process often prevents plant productivity by inhibiting oxygen diffusion to the roots (Sorrell et al., 2002). The anatomical structure of the roots is important to adapt to anoxic environments for wetland types (Sorrell et al., 2002; Colmer, 2003). Also, some advanced research has shown that the response of plants to waterlogging may be 
due to roots morphology modifications like thickness of root, absence of lateral roots and reduction in root system (Wheeler, 1999; Visser et al., 2000; Romeu et al., 2019). Root propagation is important for plant growth, and the ability of nutrient acquisition depend on root length and structure in heterogeneous environments (Wahl et al., 2001). Vartapetian and Jackson (1997) stated that growth of roots under hypoxia or oxygen deficiency leads to confusion in oxygen-dependent pathways, especially the power generation system, functional relationships between roots and stem and both carbon absorption and photosynthesis. Wetland plants adapt to anaerobic conditions by formation of air roots containing intensive aerenchyma cavities to promote internal oxygen transport (Jackson and Armstrong, 1999; Visser et al., 2000; Colmer, 2003). Lysigenous and schizogenous aerenchyma disturbed in many important crop plant species and tissues (Justin and Armstrong, 1987; Jackson and Armstrong, 1999; Gunawardena et al., 2001). Also, schizogeneous aerenchyma was recorded in some wetland species like Rumex palustris and Ranunculus sceleratus (Visser et al., 2000). Some species such as Sagittaria lancifolia tend to form both schizogenous and lysigenous aerenchyma (Schussler et al., 1997). Our objective was to study the response of growth, nodulation, nodule activity and anatomy of faba bean plant roots under the effect of both water stresses (water deficit or waterlogging). Also, this study aimed to compare the differential response of Vicia faba plants to water deficit and waterlogging.

\section{Materials and methods}

Surface sterilized seeds of faba bean (Vicia faba) plants were conducted at the greenhouse chamber. Ten seeds were sown in culture pots containing $3 \mathrm{~kg}$ clay (Three pots for each treatment) and treated as follow. The pots were irrigated with tap water until reach field capacity is referred as control. Two weeks old seedlings were subjected to the following treatment: First group of pots irrigated until reach flooding, 2 FC (WL), second group of pots were irrigated till reach $75 \%$ of FC (LWD) and the third group of pots irrigated tell reach $50 \%$ of FC (HWD) for two weeks. At the early vegetative stage and after 2-weeks of treatments, plants were separated into roots and shoots. Results of fresh and dry weights of the roots and shoots will be recorded. Another part of fresh roots and shoots were stored in liquid nitrogen and stored at $-80^{\circ} \mathrm{C}$ for experimental analysis. Nodule number, nodule fresh and dry weights were recorded. The activity nitrogenase enzyme was measured as described previously by Abd-Alla (1992) using the method recorded by Larue and Kurz (1973). Save each bottle at room temperature with 5\% (T/T) acetylene for 1 hour and the emitted ethylene in the reaction bottle was measured by a gas chromatograph (Thermo Scientific TRACE GC Ultra equipped with FID detector). The enzyme activity was calculated as the $\mu \mathrm{mol}$ acetylene $/ \mathrm{h} / \mathrm{g}$ nodule fresh weight. Determination of nodules leghemoglobin was recorded after 45 days of plant growth by the method of Becana et al. (1986). One gram of detached nodules were ground in a mortar and pestle under cooling and macerated with $2 \mathrm{ml} \mathrm{KCN}$, then centrifuged at $10,000 \mathrm{rpm}$ for $30 \mathrm{~min}$ in a refrigerated centrifuge. The supernatants were reduced with sodium dithionate and the absorbance was recorded at $540 \mathrm{~nm}$. Oxhemoglobin was used as a standard for calculations.

\section{Alcohol dehydrogenase activity and its kinetics}

$0.5 \mathrm{~g}$ of leaf tissues were mined in $5 \mathrm{ml}$ of $100 \mathrm{mM} \mathrm{K}$-phosphate buffer $(\mathrm{pH} \mathrm{7.8)}$ containing 0.1 EDTA and $0.1 \mathrm{~g}$ polyvinylpyrrolidone. The mixture was centrifuged at 
$15,000 \mathrm{rpm}$ for $15 \mathrm{~min}$ and the supernatants were used for measuring the activity of alcohol dehydrogenase enzyme (ADH). The enzyme activity was measured by monitoring NADH oxidation at $340 \mathrm{~nm}$ according to Yamanoshita et al. (2005) and modified by Govinda and Shanta (2011). The reaction medium was activated by addition of different volumes $(50,100,150$ and $200 \mu \mathrm{l}$ of $2.4 \mathrm{mM} \mathrm{NADH}$ and extract) and the reaction was initiated with $0.3 \mathrm{M}$ acetaldehyde.

\section{Root anatomy}

Five root sections were collected from different plant treatment and immediately fixed in $2 \%$ paraformaldehyde, $2 \%$ glutaraldehyde, and $100 \mathrm{mM}$ sodium cacodylate buffer, $\mathrm{pH}$ 7.35 for sectioning. Fixed prepared tissues were then rinsed with $100 \mathrm{mM}$ sodium cacodylate buffer (pH 7.35) containing $10 \mathrm{mM}$ 2-mercaptoethanol and $130 \mathrm{mM}$ sucrose. These sections were stained using Sato's triple lead solution stain and 5\% aqueous uranyl acetate (Sato, 1968). After infiltration with Spurr's resin (Spurr, 1969) and polymerization, ultrathin sections $(60-90 \mathrm{~nm})$ were cut with an ultramicrotome, contrasted with uranyl acetate and lead citrate, and examined with a transmission electron microscope (JEOL TEM 100 CXII, Electron Microscope Unit, Assiut University).

\section{Statistical analysis}

One-way ANOVA using the SPSS 10.0 software program. Means and standard errors were calculated for three replicate values. Means were compared by the Duncan's multiple range test and statistical significance was determined at 5\% level.

\section{Experimental results}

\section{Growth criteria}

Faba plants grow under controlled conditions did not show any symptoms of leaf damage over the longest experimental period. Waterlogging stress induce visible leaf damage was apparent after 20 days of planting, like midrib yellowing, leaf yellow spots and finally wilting, their progression was very rapid. The results of roots and shoots of bean plants grown under water logging and water deficit stresses are presented in Figure 1. These results indicate that the stress of water deficit significantly reduced the fresh and dry weights of the roots and shoots of faba bean plants, especially developing at high droughted level (50\% FC).

Both stresses flooding and high water deficit reduced significantly the total biomass of faba bean (Vicia faba) plants. Water deficit level (50\% FC) significantly reduced roots fresh and dry weights more than low water deficit level (75\% FC) as compared to control plants. Whereas, roots dry weight of flooded treatment was seems higher and this sometimes occurs at least in part as the result of initiation of several new lateral roots under flooding condition on the sub- merged part of shoot.

\section{Number of nodules}

The results of nodule number are presented in Table 1, these results showed that the levels of drought $(75 \% \& 50 \%$ FC) was significantly lowered the number of nodules per plant by about $5 \%$ and $47 \%$, respectively. Also, the waterlogging stress significantly decreased the number of nodules by about $52.2 \%$. 


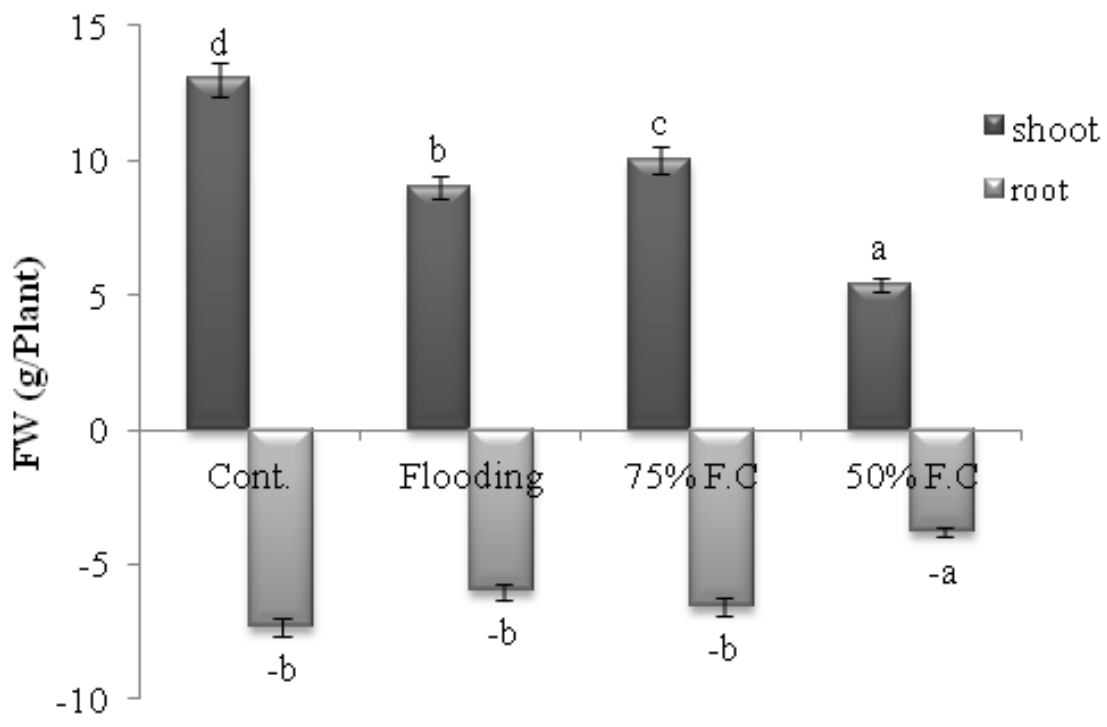

a

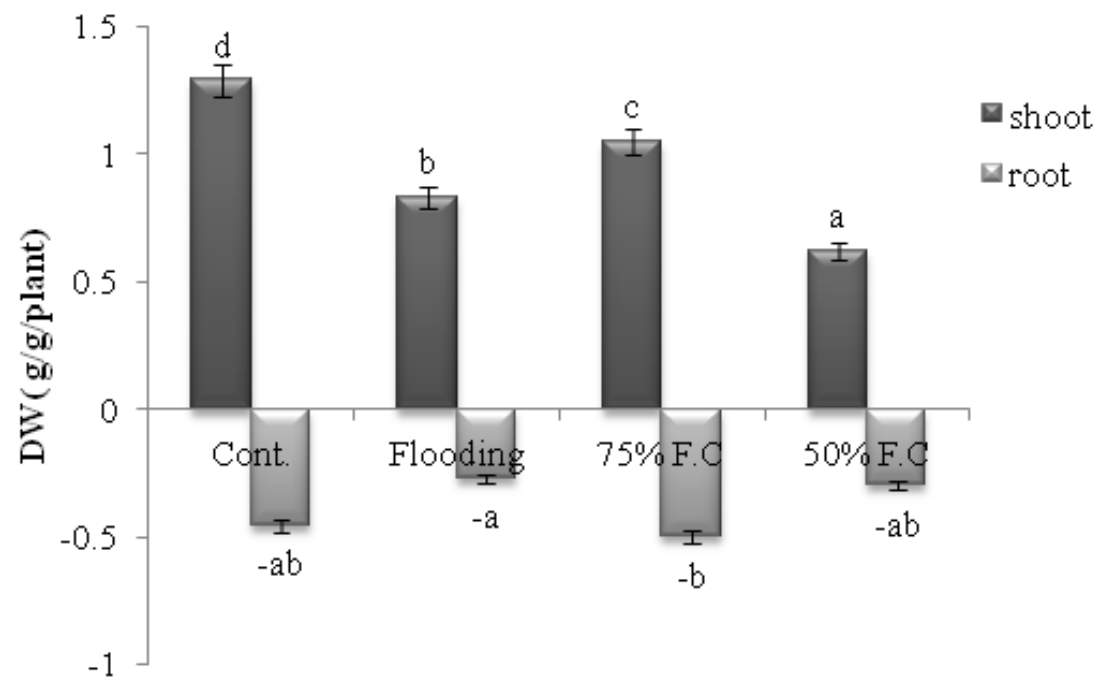

b

Figure 1. Fresh weights of roots and shoots $(a)$ and roots and shoots dry weights $(b)$ of faba bean plants grown under different levels of field capacity for two weeks. The same letters indicate non- significant differences between treatments at $P<0.01$

Table 1. Effect of water deficit and waterlogging on nodules number, nodule leghemoglobin and nitrogenase activity of faba bean plants grown under different levels of field capacities for two weeks

\begin{tabular}{c|c|c|c}
\hline \multirow{2}{*}{ Treatments } & \multicolumn{3}{|c}{ Vicia faba plants } \\
\cline { 2 - 4 } & $\begin{array}{c}\text { Number of } \\
\text { nodules/plant }\end{array}$ & Nodule leghemoglobin & Nitrogenase activity \\
\hline Control & $115 \pm 8.3^{\mathrm{d}}$ & $0.33 \pm 0.02^{\mathrm{c}}$ & $6.32 \pm 7.36^{\mathrm{c}}$ \\
Flooding (2 FC) & $60 \pm 4^{\mathrm{c}}$ & $0.19 \pm 0.01^{\mathrm{a}}$ & $0.69 \pm 0.17^{\mathrm{a}}$ \\
LWD (57\% FC) & $35 \pm 6.2^{\mathrm{b}}$ & $0.27 \pm 0.1^{\mathrm{b}}$ & $5.38 \pm 3.11^{\mathrm{c}}$ \\
HWD (50\% FC) & $13 \pm 2^{\mathrm{a}}$ & $0.23 \pm 0.01^{\mathrm{b}}$ & $1.16 \pm 0.3^{\mathrm{b}}$ \\
\hline
\end{tabular}

The same letters indicate non-significant differences between treatments at $\mathrm{P}<0.05$ 


\section{Nodule leghemoglobin content}

Table 1 showed that the number of nodules significantly reduced at highest level of drought (50\% FC) and flooding (2 FC). Also, nodule leghemoglobin content was decreased significantly as a result water stress imposed to the both levels of drought ( $75 \%$ \& 50\% FC) and flooding. The percentage of reduction in nodule leghemoglobin content of root nodules was $81 \%$ and $63 \%$ respectively. The results also showed that, nodule leghemoglobin content was decreased significantly under waerlogging.

The results in Table 1 revealed that the activity of nitrogenase enzyme was significantly decreased especially at the level of $50 \%$ FC. The percentage of decrease was reached $85 \%$. Also, the data showed that, a significant decrease in the activity of nitrogenase enzyme in faba bean under flooding treatment.

\section{ADH activity and kinetics}

Alcohol dehydrogenase (ADH) activity and specific activity are presented in Figure 2. The data expressed as $\Delta$ abs. at $340 \mathrm{~nm} \mathrm{~min}^{-1} \mathrm{mg}^{-1} \mathrm{FW}$ and $\Delta$ abs. at $340 \mathrm{~nm}$ $\mathrm{min}^{-1} \mathrm{mg}^{-1}$ protein, respectively. The specific activity of ADH ( $\Delta$ abs. at $340 \mathrm{~nm} \mathrm{~min}{ }^{-1}$ $\mathrm{mg}^{-1} \mathrm{FW}$ ) of plant roots grown under flooding treatment was increased as compared to control. Whereas, the activity and specific activity of ADH enzyme was significantly decreased under the two level of water deficit $(75 \%$ and $50 \% \mathrm{FC})$ as compared to absolute control.

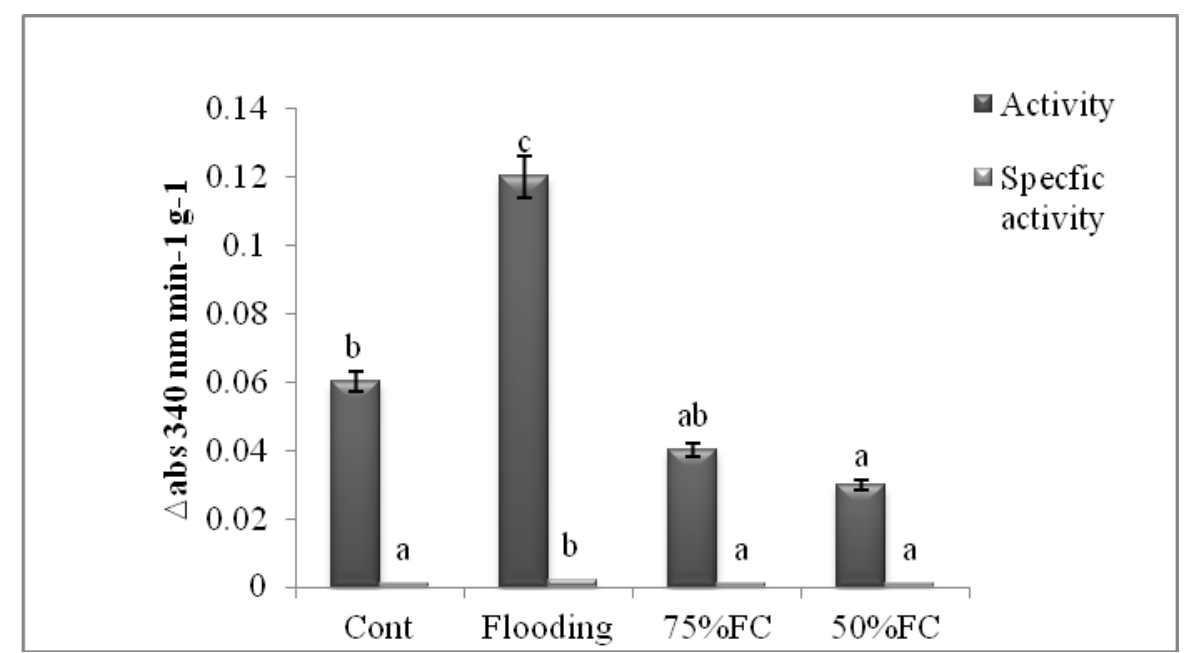

Figure 2. Alcohol dehydrogenase activity ( $\triangle$ abs. at $340 \mathrm{~nm} \mathrm{~min}^{-1} \mathrm{mg}^{-1} \mathrm{FW}$ ) and specific activity ( $\triangle$ abs. at $340 \mathrm{~nm} \mathrm{~min}^{-1} \mathrm{mg}^{-1}$ protein) of faba bean plant roots grown under the different level of field capacity. The same letters indicate non-significant differences between treatments at

$$
P<0.01
$$

Lineweaver-Burk plots for Alcohol dehydrogenase (ADH; EC 1.11.1.11) enzyme that was extracted from roots of bean plants grown under flooding and drought are result in the production of lines with different slops and intercepts for ADH activity which presented in Figure 3. The intercepts on $\mathrm{X}$-axis $\left(\mathrm{K}_{\mathrm{m}}\right)$, intercepts of $\mathrm{y}$-axis $\left(\mathrm{V}_{\max }\right)$ and Kcat of the different lines. Michael's constant $\left(\mathrm{K}_{\mathrm{m}}\right)$ and maximum velocity $\left(\mathrm{V}_{\max }\right)$ of $\mathrm{ADH}$ in roots of bean plants grown under both level of drought $(75 \% \& 50 \% \mathrm{FC})$ of treatments were decreased as compared to absolute control. 


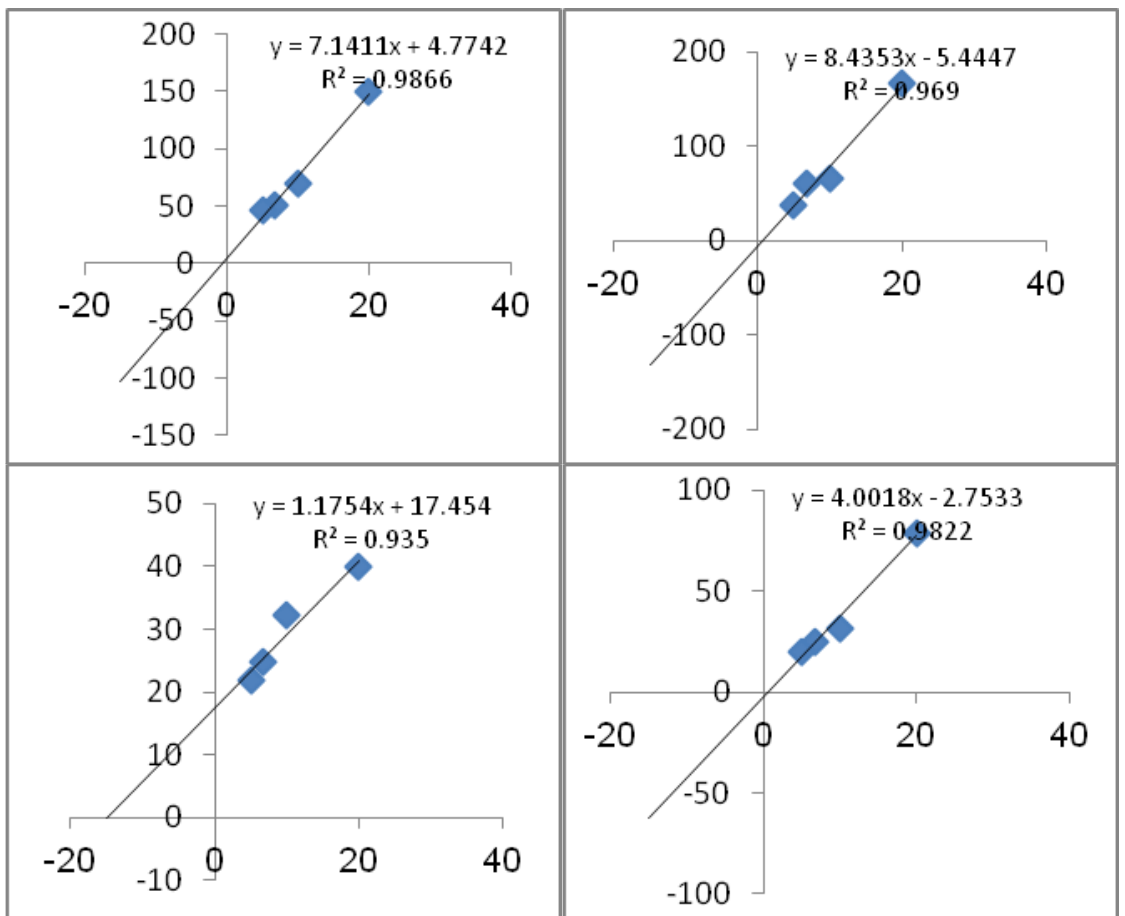

Figure 3. Lineweaver-Burk plots for alcohol dehydrogenase (ADH; EC 1.11.1.11) enzyme of Vicia faba plants grown for 2- weeks under water deficit (LWD \& HWD) and flooding

\section{Anatomy of root}

Transverse sections of plant roots grown under high water deficit and flooding compared to control plant were investigated (Fig. 4). The photos showed that aerenchyma was found in the T.S root tested plants under flooding stress as shown in Figure 4 as compared to plant control. However, under drought we found accumulation of solutes in the parenchyma cells compared to plant control, but didn't recorded in bean plants as shown in the same Figure 4. A cross section of control plants section of central tissue cells contains normal parenchymal cells. B-Cortical tissue showing compact parenchymal cells with few intercellular spaces. C- Cortical cells showing loosely parenchymal cell containing many and large intercellular spaces (aerenchyma).

\section{Discussion}

The effectiveness of WL and WD on roots and shoots growth of tested faba bean plants are shown in Figure 1. The results showed that water stress (WD or WL) significantly reduced the fresh and dry weights of the roots and shoots of faba bean plants, especially when the water shortage reached (50\% FC).

Waterlogging and high water deficit stresses significantly decreased the total biomass of faba bean (Vicia faba) plants grown under the both stresses. These data are in agreement with many investigators (Sorrell et al., 2000; Chen et al., 2002). Water stress affects the growth of plant organs by alteration of morphological features of the plants (French and Turner, 1991; Cox and Conran, 1996). The mechanisms involved in the adaptation of plants to water deficit is the change in root to shoot dry mass ratio (Turner, 1997; El-Enany et al., 2013). The reduction in water availability results in 
growth inhibition, reduced shoot and root growth of bean plant. Reduction in tissue dry weights during drought stress may be due to decrease in plant growth, photosynthesis, cell expansion and cell division (Sundaravalli, et al., 2005; Rodriguez et al., 2008).

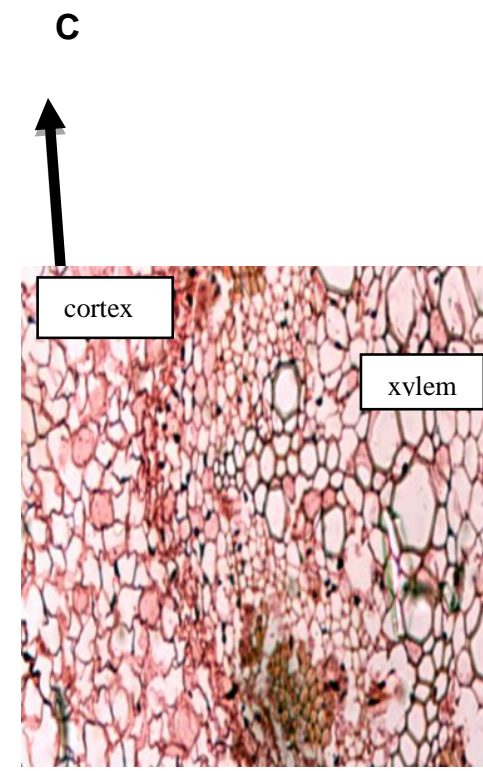

a Control

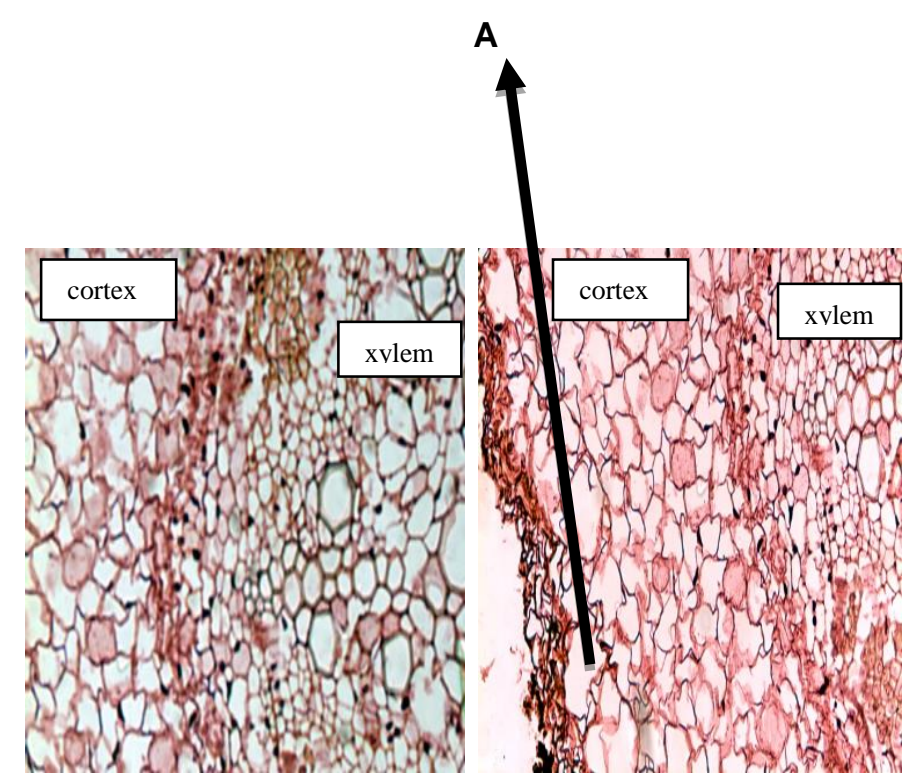

b Water deficit

c Flooded root

Figure 4. Transfers cross sections of 3-weeks old of faba been roots stained with safranin examined and photographed at $25 \mathrm{X}$. A: aerenchyma resulted from lyses of some cortex parenchyma as compared to $C$ : normal cortex in control roots

Our results indicated that the no. of nodules per plant was significantly decreased under both drought and flooding (Table 1). Streeter (2003) and González et al. (2010) concluded that the severely effects on nodulation occur during the establishment of the symbiosis and formation of nodules. Many studies have shown that water deficit negatively affects the stabilization of biological nitrogen fixation by reducing the number of nodules and the activity of nitrogen fixing enzymes (Abd-Alla et al., 2001; Ashraf and Iram, 2005; Christophe et al., 2011; Silvente et al., 2012). In addition, stress may reduce the invasion of leguminous plant roots by living rhizobia in the soil (Latrach et al., 2014; Mouradi et al., 2016). Charlson et al. (2009) reported that the nitrogen fixation in legume plants reduced under drought stress and may due to (i) the accumulation of ureides in both nodules and shoots, (ii) minimize in shoot nitrogen demand, (iii) reduce transpiration rate and thus lower xylem translocation rate and (iv) the decline of metabolic enzyme activity.

Table 2 showed that nitrogenase activity was significantly affected by drought and flooding, This may be due to lowered oxygen diffusion to the bacteroids, thus depressing nodule respiration and consequently nitrogenase activity (Guerin et al., 1990). This process usually involves increased production of oxygen free radicals species such as $\mathrm{H}_{2} \mathrm{O}_{2}, \mathrm{O}_{2}$, and $\mathrm{OH}$ (Becana et al., 1986). Legume nodules possess a number of enzymatic mechanisms to minimize the toxicity of active oxygen species, including superoxide-dismutase, catalase and peroxidase (Becana et al., 1986). Inhibition of the nitrogen-fixing activities of nodules by waterlogging may by the 
decreased by the bacteroids synthesis of nitrogenase (Bisseling et al., 1980), or by minimizing carbohydrate metabolism of host tissue in the nodule and/or decline in leghemoglobin content (Huang and LaRue, 1985). Higher leghemoglobin content was observed in the nodules of waterlogged plant (Table 2) and this may be facilitates the diffusion of oxygen from the nodule surface to the bacteriod and increase biological nitrogen fixation. This was also observed by Huang and LaRue (1985).

Table 2. Vmax and $\mathrm{Km}$ and Kcat and $\mathrm{Km} /$ Kcat of alcohol dehydrogenase activity (ADH) of faba bean plant roots grown under water deficit and waterlogging

\begin{tabular}{c|c|c|c|c}
\hline \multirow{2}{*}{ Parameters } & \multicolumn{4}{|c}{ Faba bean plants } \\
\cline { 2 - 5 } & Cont. & Flooding & $\mathbf{7 5 \%}$ F.C. & $\mathbf{5 0 \%}$ F.C. \\
\hline Vmax & 3.13 & 0.06 & 0.18 & 0.21 \\
Km & 12.42 & 0.07 & 1.55 & 1.50 \\
Kcat & 62.50 & 1.15 & 3.67 & 4.19 \\
Km/Kcat & 0.20 & 0.06 & 0.42 & 0.36 \\
\hline
\end{tabular}

The results in Figure 3 show that waterlogging activate alcohle dehydrogenase activity in roots more than shoots, whereas its activity not affected under different levels of water deficit. These results are consistent with Kato-Noguchi and Morokuma (2007) and Yamanoshita et al. (2005) who observed that waterlogging stimulates sugar fermentation by stimulating the activity of dehydrogenase of roots. Also, (Kang et al., 2009) found that activation of ethanolic fermentation was found in bean and cowpea plant to survive anaerobiosis and considered one of the strategies for growing cucmber seedling under waterlogging. The survival of seedling for many days of waterlogging may due to the oxygen available to roots through aerenchyma (Nada, et al., 2004; Yin et al., 2010). Aerenchyma formation is an important way to increase oxygen penetration from the shoots to the roots, and is essential for maintaining air diffusion, to provide a source of energy for alcoholic fermentation.

The results in Figure 4 show that formation of aerenchyma in plant roots grown under waterlogging treatment as compared with control plants. Whereas, plan roots sections appear a narrow cortex cells for faba bean plants grown under high water deficit as compared by control plant root. These results are in accordance with many investigators (Ashraf, 2003; Voesenek et al., 2006; Justin and Armstrong, 1987). Jackson and Armstrong (1999) showed that the improvement of the aeration of the rhizosphere in plants grown under flooding induced by formation of aerenchyma. Drew et al. (2000) stated that there are two different processes in plants to form aerenchyma schizogeny or lysigeny, or by their combination. Schizogenous aerenchyma involves cell wall reorganization and cell separation, whereas lysigenous aerenchyma formed by cell death) and cell wall autolysis (Gunawardena et al., 2001; Evans, 2003). Suralta and Yamauchi (2008) and Joshi and Kumer (2012) explained that the formation of aerenchyma tissue may facilitate oxygen aggregation in submerged tissues and reduce hypoxia of waterlogged seedlings. Larger intercellular spaces formed in faba bean plants may improved the plant's capacity for oxygen aggregation and exchange gases within the submerged parts of plants. 


\section{Conclusion}

Faba bean plant is significantly affected by water deficit and waterlogging during the vegetative stage. Our data stated that the flooding cause damage to Vicia faba plant more than water deficit through its effects on nodule formation and activity. The findings of current study support previous conclusion that ADH enzyme activity and root anatomy can be used as a bioindicator for waterlogging or water deficit stress in legume plants and thereby playing an important role in flooding stress tolerance and signaling in crop plant.

\section{REFERENCES}

[1] Abd-Alla, M. H. (1992): Nodulation and nitrogen fixation in faba bean (Vicia faba L.) plants under salt stress. - Symbiosis 12: 311-319.

[2] Armstrong, W. (1971a): Radial oxygen losses from intact rice roots as affected by distance from the apex, respiration and waterlogging. - Physiologia Plantarum 25: 192197.

[3] Armstrong, W. (1971b): Oxygen diffusion from the roots of rice grown under non waterlogged conditions. - Physiologia Plantarum 24: 242-247.

[4] Araus, J. L., Slafer, G. A., Reynolds, M. P., Royo, C. (2002): Plant breeding and drought in $\mathrm{C}_{3}$ cereals: What should we breed for? - Annals of Botany 89: 925-940.

[5] Asgher, M., Per, T. S., Masood, A., Fatma, M., Freschi, L., Corpas, F. J., Khan, N. A. (2017): Nitric oxide signaling and its crosstalk with other plant growth regulators in plant responses to abiotic stress. - Environmental Science Pollution Research 24: 2273-2285.

[6] Ashraf, M. (2003): Relationships between leaf gas exchange characteristics and growth of differently adapted populations of Blue panicgrass (Panicum antidotale Retz) under salinity or waterlogging. - Plant Science 165: 69-75.

[7] Ashraf, M., Iram, A. (2005): Drought stress induced changes in some organic substances in nodules and other plant parts of two potential legumes differing in salt tolerance. Flora 200: 535-546.

[8] Becana, M. S., Aparicio-Tejo, P., Pena, J., Aguirreolea, J., Sánchez, D. M. (1986): N2fixation and leghemoglobin content during nitrate and water stress induced senescence of Medicago sativa root nodules. - J of Experimental Botany 37: 597-605.

[9] Bisseling, S. T., van Staveren, W., van Kammen, A. (1980): The effect of waterlogging on the synthesis of the nitrogenase components in bacteroids of Rhizobium leguminosarium in root nodules of Pisum. - Biochemical and Biophysical Research Commmunication 93: 687-693.

[10] Boyer, J. S. (1982): Plant productivity and environment. - Science, 218: 443-448.

[11] Candan, N., Tarhan, L. (2012): Tolerance or sensitivity responses of Mentha pulegium to osmotic and waterlogging stress in terms of antioxidant defense systems and membrane lipid peroxidation. - Environmental and Experimental Botany 75: 83-88.

[12] Charlson, D. V., Bhatnagar, S., King, C. A., Ray, J., Sneller, C., Carter, T. (2009): Polygenic inheritance of canopy wilting in soybean (Glycine max (L.) Merr). Theorotical and Applied Genetics 119: 587-594.

[13] Chen, H., Qualls, R. G., Miller, G. C. (2002): Adaptive responses of Lepidium latifolium to soil flooding: biomass allocation, adventitious rooting, aerenchyma formation and ethylene production. - Environmental and Experimental Botany 48: 119-128.

[14] Christophe, S., Jean-Christophe, A., Annabelle, L., Alain, O., Marion, P., Anne-Sophie, V. (2011): Plant N Fluxes and Modulation by Nitrogen, Heat and Water Stresses: A Review Based on Plants. - In: Shanker, A., Venkateswarlu, B. (eds.) Abiotic Stress in Plants. Mechanisms and Adaptations. InTech, Rijeka, Croatia. 
[15] Colmer, T. D. (2003): Aerenchyma and an inducible barrier to radial oxygen loss facilitate root aeration in upland, paddy and deepwater rice (Oryza sativa L.). - Annals of Botany 91: 301-309.

[16] Cox, J. A., Conran, J. G. (1996): The effect of water stress on the life cycles of Erodium crinitum Carolin and Erodium cicutarium (L.) L'Herit. ex Aiton (Geraniaceae). Australia Journal of Ecology 21: 235-240.

[17] Cutler, J. M., Shahan, K. W., Steponkus, P. L. (1980): Influence of water deficits and osmotic adjustment on leaf elongation in rice. - Crop Science 20: 314-318.

[18] Drew, M. C. (1997): Oxygen deficiency and root metabolism: injury and acclimation under hypoxia and anoxia. - Annual Review Plant Biology 48: 223-250.

[19] El-Enany, A. E., AL-Anazi, A. D., Dief, N., Al-Taisan, W. A. (2013): Role of antioxidant enzymes in amelioration of water deficit and waterlogging stresses on Vigna sinensis plants. - Journal of Biology and Earth Sciences 3: B144-B153.

[20] El-Enany, A. E., Morsy, F., Dief, N. (2014): Impact of water stress on growth criteria and alcohol dehydrogenase activity of three legume plants. - Minia Science Bulletin 25: 2951 .

[21] Evans, D. E. (2003): Aerenchyma formation. - New Phytol. 161: 35-49.

[22] French, R. J., Turner, N. C. (1991): Water deficits change dry matter partitioning and seed yield in narrow-leafed lupins (Lupinus angustifolius L.). - Australian Journal of Agricultural Research 42: 471-484.

[23] Gao, J.-P, Chao, D-Y., Lin, H-X. (2007): Understanding abiotic stress tolerance mechanisms: recent studies on stress response in rice. - Journal of Integrative Plant Biology 49: 742-750.

[24] Gonzalez, E. M., Gordon, A. J., James, C. L., Arrese-Igor, C. (1995): The role of sucrose synthase in the response of soybean nodules to drought. - Journal of Experimental Botany 46: 1515-1523.

[25] Govinda, R., Shanta, K. (2011): Alcohol dehydrogenase (ADH) activity in soybean (Glycine max L.] Merr.) under flooding stress Electronic. - Journal of Plant Breeding 2: 50-57.

[26] Gunawardena, A., Pearce, D. M., Jackson, M. B., Hawes, C. R., Evans, D. E. (2001): Characterization of programmed cell death during aerenhyma formation induced by ethylene or hypoxia in roots of maize (Zea mays L.). - Planta 212: 205-214.

[27] Hsiao, T. C., Silk, W. K., Jing, J. (1985): Leaf Growth and Water Deficits: Biophysical Effects. - In: Baker, N. R., Davies, W. J., Ong, C. K. (eds.) Control of Leaf Growth. Society for Exp. Biol. Seminar Series 27. Cambridge University Press, Cambridge, pp 239-266.

[28] Huang, C. Y., LaRue, T. A. (1985): Effects of waterlogging on the nitrogen fixation and carbohydrate metabolism in nodules of soybean plant. - Proceeding of The National Science Council B. ROC 9: 82-88.

[29] Hussain, M., Farooq, S., Hasan, W., Ul-Allah, S., Tanveer, M., Farooq, M., Nawaz, A. (2018): Drought stress in sunflower: physiological effects and its management through breeding and agronomic alternatives. - Agricultural Water Management 201: 152-166.

[30] Jackson, M. B., Armstrong, W. (1999): Formation of aerenchyma and the processes of plant ventilation in relation to soil flooding and submergence. - Plant Biology 1: 274287.

[31] Joshi, R., Kumar, P. (2012): Lysigenous aerenchyma formation involves non-apoptotic programmed cell death in rice (Oryza sativa L.) roots. - Physiology and Molecular Biology of Plants 18: 1-9.

[32] Justin, S. H., Armstrong, W. (1987): The anatomical characteristics of roots and plant response to soil flooding. - New Phytologist 106: 465-495.

[33] Kang, T. W., Adesogan, A. T., Kim, S. C., Lee, S. S. (2009): Effects of esteraseproducing inoculants on fermentation, aerobic stability, and neutral detergent fiber digestibility of corn silage. - Journal of Dairy Science 92: 732-738. 
[34] Kato-Noguchi, H., Morokuma, M. (2007): Ethanolic fermentation and anoxia tolerance in four rice cultivars. - Journal of Plant Physiology 164: 168-173.

[35] LaRue, T. A., Kurz, W. G. W. (1973): Estimation of nitrogenase using a colorimetric determination for ethylene. - Plant Physiology 51: 1074-1075.

[36] Latrach, L., Farissi, M., Mouradi, M., Makoudi, B., Bouizgaren, A., Ghoulam, C. (2014): Growth and nodulation of alfalfa-rhizobia symbiosis under salinity: electrolyte leakage, stomatal conductance, and chlorophyll fluorescence. - Turkish Journal of Agriculture and Forestry 38: 320-326.

[37] Mittler, R. (2006): Abiotic stress, the field environment and stress combination. - Trends in Plant Science 11: 15-19.

[38] Mouradi, M., Farissi, M., Bouizgaren, A., Makoudi, B., Kabbadj, A. Very, A. A Sentenac, H., Qaddourya, A., Ghoulam, C. (2016): Effects of water deficit on growth, nodulation and physiological and biochemical processes in Medicago sativa-rhizobia symbiotic association. - Arid Land Research and Management 30: 193-208.

[39] Nada, K., Iwatani, E., Doi, T., Tachibana, S. (2004): Effect of putrescine pretreatment to roots on growth and lactate metabolism in the root of tomato (Lycopersicon esculentum Mill.) under root-zone hypoxia. - Journal Japanese of Society for Horticultural Science 73: 337-339.

[40] Parent, C., Berger, A., Folzer, H., Dat, J., Crevecoeur, M., Badot, P-M., Capelli, N. (2008): A novel nonsymbiotic hemoglobin from oak: Cellular and tissue specificity of gene expression. - New Phytologist 177: 142-154.

[41] Rodriguez, H. J., Volkenburgh, E. V., Hoy, M., Wright, L., Beckwith, F., Kim, Y-K., Regina, S. R. (2008): Stress tolerance in plants via habitat-adapted symbiosis. - The ISME Journal 2: 404-416.

[42] Romeu, d. S. L., Marilza, N. d. N., Tamara, T. T., Lourival, P. G. N., Cristiane, A. d. S. R., Alismrio, L. d. S. (2019): Alleviation of water deficit in Physalis angulata plants by nitric oxide exogenous donor. - Agricultural Water Management 216: 98-104.

[43] Sato, T. (1968): A modified method for lead staining of thin sections. - Journal Electron Microscope 17: 158.

[44] Schussler, E. E., Borkhsenious, O. N., Longstreth, D. J. (1997): Formation of root aerenchyma involves programmed cell death in Saggittaria lancifolia. - Plant Physiology 114: 456-456.

[45] Silvente, S., Sobolev, A. P., Lara, M. (2012): Metabolite adjustments in drought tolerant and sensitive soybean genotypes in response to water stress. - PLoS One 7: 38554.

[46] Sorrell, B. K., Downes, M. T., Stanger, C. L. (2002): Methanotrophic bacteria and their activity on submerged aquatic macrophytes. - Aquatic Botany 72: 107-119.

[47] Spurr, A. R. (1969): A Low-Viscosity epoxy resin embedding medium for electron microscopy. - Journal of Ultrastructure Research 26: 31-43.

[48] Streeter, J. G. (2003): Effects of drought on nitrogen fixation in soybean root nodules. Plant Cell Environment 26: 1199-1204.

[49] Sundarvalli, M. V., Paliwal, K., Ruckmani, A. (2005): Effect of water stress on photosynthesis, protein content and nitrate reductase activity of Albizzia seedlings. Journal of Plant Biology 32: 13-17.

[50] Suralta, R., Yamauchi, A. (2008): Root growth, aerenchyma development and oxygen transport in rice genotypes subjected to drought and waterlogging. - Environmental and Experimental Botany 64: 75-82.

[51] Turner, N. C. (1997): Further progress in crop water relations. - Advances in Agronomy 58: 293-338.

[52] Vartapetian, B. B., Jackson, M. B. (1997): Plant adaptation to anaerobic stress. - Annals of Botany 79: 3-20.

[53] Visser, E. J. W., Colmer, T. D., Blom, C. W. P. M., Voesenek, L. A. C. J. (2000): Changes in growth, porosity, and radial oxygen loss from adventitious roots of selected 
mono and dicotyledonous wetland species with contrasting types of aerenchyma. - Plant, Cell and Environment 23: 1237-1245.

[54] Voesenek, L. A. C. J., Colmer, T. D., Pierik, R., Millenaar, F. F., Peeters, A. J. M. (2006): How plants cope with complete submergence. - New Phytologist 170: 213-226.

[55] Wahl, S., Ryser, P., Edwards, P. J. (2001): Phenotypic plasticity of grass root anatomy in response to light intensity and nutrient supply. - Annals of Botany 88: 1071-1078.

[56] Wheeler, B. D. (1999): Water and Plants in Freshwater Wetlands. - In: Baird, A. J., Wilby, R. L. (eds.) Eco-Hydrology. Routledge, London, pp. 127-180.

[57] Yamanoshita, T., Masumori, M., Yagi, H., Kojima, K. (2005): Effects of flooding on downstream processes of glycolysis and fermentation in roots of Melaleuca cajuputi seedlings. - Journal of Forest Research 10: 199-204.

[58] Yin, D., Fadi, C. S., Zhi, C., Fang, W. (2010): Morpho-anatomical and physiological responses of two Dendranthema species to waterlogging. - Environmental and Experimental Botany 68(2): 122-130. 